\title{
Improvement the nutritional status of pre-school children following intervention with a supplement containing iron, zinc, copper, vitamin A, vitamin C and prebiotic
}

\author{
Melhoria no estado nutricional de pré-escolares \\ após intervenção com suplemento contendo ferro, zinco, \\ cobre, vitamina A, vitamina C e prebiótico
}

Luiza Carla Vidigal Castro ${ }^{1}$

Neuza Maria Brunoro Costa ${ }^{2}$

Helena Maria Pinheiro Sant'Anna ${ }^{1}$

Célia Lucia de Luces Fortes Ferreira ${ }^{3}$

Sylvia do Carmo de Castro Franceschini ${ }^{1}$

${ }^{1}$ Departamento de Nutrição e Saúde, Universidade Federal de Viçosa (UFV). Av. PH Rolfs SN/Prédio CCB

II/ $/ 5^{\circ}$ andar/sala 14, Campus Universitário. 36570-900

Viçosa MG Brasil. luiza. castro@ufv.br

${ }^{2}$ Departamento de Farmácia e Nutrição, Universidade Federal do Espírito Santo. Alegre ES Brasil.

${ }^{3}$ Departamento de

Tecnologia de Alimentos,

UFV. Viçosa MG Brasil.
Abstract This study investigated the effects of a vitamin and mineral fortified powder product supplemented with inulin, on the iron and vitamin A status of 110 pre-schools childrens in Viçosa, MG, Brazil. The 2 to 5-year-old children were submitted to anthropometric (weight and height), biochemical (erythrocytes, hemoglobin, mean corpuscular volume-MCV, mean corpuscular hemoglobin - MCH, serum iron, ferritin and serum retinol) and dietary (direct food weighing, $24 \mathrm{~h}$ recall, and food intake record) evaluations, at the beginning and at the end of a 45-day intervention. The supplement $(30 \mathrm{~g})$ was provided daily as part of the afternoon snack, diluted in $100 \mathrm{~mL}$ of water, 5 times/week and it supplied 30\% of the recommended daily doses of iron, zinc, copper and vitamins $A$ and C. Dietary and biochemical data was compared by the Wilcoxon test, and anthropometric data by the paired t-test. Values of z-scores for weight and height, erythrocytes, hemoglobin, $M C V, M C H$ and ferritin were significantly higher after intervention; no change was observed in serum retinol. The prebiotic-containing supplement significantly increased the intake of energy, macro and micronutrients, and was effective in improving the iron and anthropometric status.

Key words Supplement, Prebiotic, Iron, Retinol, Nutritional status, Preschool children
Resumo Este estudo investigou os efeitos de um produto em pó fortificado com vitaminas e minerais e suplementado com inulina, no estado nutricional de ferro e vitamina $A$ de 110 crianças pré-escolares do município de Viçosa, MG, Brasil. As crianças, de 2 a 5 anos de idade, foram submetidos às avaliações antropométrica (peso e altura), bioquímica (eritrócitos, hemoglobina, volume corpuscular médio - VCM, hemoglobina corpuscular média - HCM, ferro sérico, ferritina e retinol sérico) e dietética (pesagem direta dos alimentos, recordatório de 24 h e registro alimentar), no início e ao final de uma intervenção de 45 dias. $O$ suplemento $(30 \mathrm{~g})$ foi ministrado diariamente no lanche da tarde, diluído em $100 \mathrm{ml}$ de água, 5 vezes/semana, fornecendo $30 \%$ das doses diárias recomendadas de ferro, zinco, cobre e vitaminas A e C. Os dados dietéticos e bioquímicos foram comparados pelo teste de Wilcoxon e, para os dados antropométricos, utilizou-se o teste-t pareado. Os valores de z-escore (peso e altura), eritrócitos, hemoglobina, VCM, HCM e ferritina foram significativamente maiores após a intervenção; nenhuma mudança foi observada no retinol sérico. O suplemento aumentou significativamente a ingestão de energia, macro e micronutrientes e foi eficaz na melhoria do estado nutricional de ferro e antropométrico. Palavras-chave Suplemento, Prebiótico, Ferro, Retinol, Estado nutricional, Pré-escolares 


\section{Introduction}

Food fortification is an efficient strategy to overcome iron and vitamin A deficiencies, particularly among the most vulnerable population groups, such as preschool children ${ }^{1-5}$. Iron and vitamin A deficiencies are still significant in Brazil and many countries where their high prevalence and impact on public health is of concern ${ }^{5}$. The magnitude of such deficiencies requires specific and long-term interventions to improve the nutritional status of the target groups.

Many strategies to improve iron status by food fortification have been successfully tested. For instance, the iron-amino acid chelate fortified beverage supplemented with probiotics exerted a positive effect on iron and nutritional status of preschool children in our previous 101day study ${ }^{6}$. The short shelf life of the product and the necessity of refrigeration for transport and storage raised its cost and limited its applicability for larger low-income groups and long-term interventions. Moreover, the deficiency of other nutrients may coexist, such as vitamin A, which interact with iron metabolism and function.

The benefits of vitamin A supplementation on iron status has been reported in multiple studies $^{7-12}$. Although its mechanisms of action are not fully established, vitamin A is supposed to improve iron absorption, mobilization from liver storage and metabolism by stimulating erithropoiese, as well as reducing infections associated with anemia ${ }^{7,13,14}$. Other vitamins, such as ascorbic acid, and minerals, including zinc and copper, are also associated with iron absorption and metabolism, and may promote important benefits to combat of iron-deficiency anemia ${ }^{15}$.

Studies have shown that provision of multiple micronutrients more effectively improves growth and iron absorption and metabolism ${ }^{16-18}$. Prebiotics, such as inulin and oligofructose, stimulate probiotic bacteria growth and fermentation which improve mineral absorption ${ }^{19,20}$ and are applicable for longer shelf-life dry products.

An attempt to improve the efficacy of the fortified-product proposed by Silva et al. ${ }^{6}$ was sought in the present study with respect to iron and vitamin A status and the practicability of intervention. Hence, inulin, minerals (iron, zinc and copper) and vitamins (A and C) were added to the product.

The benefits of a powder product fortified with prebiotics, iron, zinc, copper, vitamin $\mathrm{A}$ and vitamin $\mathrm{C}$ were investigated in preschool aged children in the current study.

\section{Methods and Materials}

\section{Subjects}

One hundred forty-two preschool children aged 2 to 5 from 4 full time public preschools located in Viçosa, MG, Brazil, were recruited for this study. A total of 111 individuals presented the assigned consent of their parents or guardians and attended the initial blood sampling. Fourteen children were excluded due to the presence of anemia (Hemoglobin $<11 \mathrm{~g} / \mathrm{dL}$ ) and/or iron reposition therapy or milk protein allergy and/or lactose intolerance. Anemic children were sent to the Health Secretary for medical treatment. The protocol was approved by the Ethics Committee for Human Studies of the Federal University of Viçosa, MG, Brazil, and by the Education Secretary of the local government.

\section{Product}

The product was processed in a Food Plant (Nutryclin Alimentos, Viçosa, MG, Brazil) under our supervision and elaborated based on a previous study ${ }^{6}$. It consisted of a prebiotic (inulin), whey protein, milk powder, sucrose, maltodextrin, vitamin mix (retinol and ascorbic acid), mineral mix (ferrous fumarate, zinc sulfate and copper sulfate), cocoa powder and chocolate flavoring (Table 1). The ingredients were mixed and the powdered product was individually packed in 30g-portion metalized packages. Vitamin and mineral contents complied with the Dietary Recommended Intakes - DRI ${ }^{21,22}$ for preschool children to fulfill $30 \%$ of their requirements in a daily portion, according to the National Health Surveillance Agency - ANVISA ${ }^{23}$.

\section{Protocol}

The study was carried out in three stages: I) Health diagnostic and nutritional status of the children (anthropometric, biochemical and dietary evaluations); II) Intervention (daily supply of the product); III) Evaluation of the intervention (anthropometric, biochemical and dietary evaluations), at the end of a 45-day intervention.

\section{Anthropometric assessment}

Weight and height of the children were measured according to Jellife ${ }^{24}$. An electronic digital portable scale with $150 \mathrm{~kg}$ capacity and 50 g precision (Kratos, Embu, SP, Brazil) was used 
Table 1. Composition of the supplement.

\begin{tabular}{lc}
\hline \multicolumn{1}{c}{ Components } & g.100 $\mathbf{~ g}^{-1}$ \\
\hline Maltodextrin $^{*}$ & 20.0 \\
Milk whey powder $^{\dagger}$ & 10.0 \\
Whey protein concentrate $^{\ddagger}$ & 15.0 \\
Whole milk powder $^{* *}$ & 18.0 \\
Sucrose $^{\dagger \dagger}$ & 19.0 \\
Vitamin (A and C) and mineral $_{\text {(Fe, Zn and Cu) mix }}^{\ddagger \dagger}$ & \\
Inulin $^{* * \star}$ & 6.0 \\
Chocolate flavor $^{\dagger \dagger \dagger}$ & 10.0 \\
Cocoa powder $^{\dagger \dagger}$ & 0.5 \\
\hline
\end{tabular}

"Corn Products (Balsa Nova, Paraná, Brasil), ${ }^{\dagger}$ Laticínios Morrinhos (Fazenda Nova, Goias, Brazil), ${ }^{\ddagger}$ Doremus Alimentos (Guarulhos, São Paulo, Brazil), ${ }^{* *}$ Montelac Alimentos (Itamonte, Minas Gerais, Brazil), ${ }^{\dagger \dagger}$ Alvinho, ${ }_{\ddagger \ddagger}^{\ddagger}$ M.Cassab, ${ }^{* * *}$ Orafti (Tienen, Belgium), ${ }^{\dagger \dagger}$ Lapiendrius Flavors (Itaquaquecetuba, São Paulo, Brazil)

for weight measurements, while height was measured by using a 2-m long and $1-\mathrm{cm}$ wide metal tape (Alturaexata, Belo Horizonte, MG, Brazil). These parameters were used to calculate the following indexes: weight for age (W/A), weight for stature (W/S), stature for age (S/A) and body mass index for age (BMI/A) compared to the reference $\mathrm{z}$-score, and classified according to the $\mathrm{WHO}^{25}$.

\section{Biochemical evaluation}

Blood samples of $6 \mathrm{~mL}$ were collected by venous puncture after $10 \mathrm{~h}$ of fasting. About $3 \mathrm{~mL}$ were transferred to tubes containing the anticlotting EDTA, for further analysis for red blood cells (RBC), hematocrit ( $\mathrm{Htc}$ ), hemoglobin ( $\mathrm{Hb}$ ) concentration, mean corpuscular volume (MCV), mean corpuscular hemoglobin $(\mathrm{MCH})$ and mean corpuscular hemoglobin concentration (MCHC) in a Coulter T-890 device (Beckman Coulter, Florida, USA). The remaining $3 \mathrm{~mL}$ were centrifuged and the serum was used to determine serum iron, ferritin and serum retinol. Serum iron was determined by the modified Goodwin method and ferritin was analyzed by immunoturbidimetry in a Cobas Mira Plus device (Roche, Basel, Switzerland) using the Bioclin kit (Quibasa, Belo Horizonte, MG, Brazil). These analytical procedures are described by Sauberlich ${ }^{26}$.

Serum retinol was quantified using a high performance liquid chromatography (HPLC) system, Shimadzu model LC-10VP (Shimadzu Corporation, Kyoto, Japan), based on the methodology used by Netto ${ }^{27}$ and Weinmann et al. ${ }^{28}$.

\section{Dietary assessment}

Direct Food Weighing was used to evaluate food intake at the preschool for breakfast, lunch and afternoon snack during 2 week-days. Food portions served and waste of the children were weighed in a digital portable scale with $2 \mathrm{~kg}$ capacity and $0.1 \mathrm{~g}$ precision (Plenna, Sao Paulo, Brazil). The data was supplemented by a 24-hour recall based on information from the child's guardian to evaluate the home-cooked meals before and after the period of stay in the preschool. In addition, guardians of the children were instructed to record food intake on one day of the weekend. Food composition was analyzed using the Diet-Pro Program version 5.1 (AS System, Viçosa, MG, Brazil). Adequacy of the nutrients was evaluated based on the Estimated Average Requirement - EAR, and the adequacy of energy was based on the Estimated Energy Requirement $-\mathrm{EER}^{21,22,29}$.

\section{Dietary intervention}

The children received a daily dose of $30 \mathrm{~g}$ of the product diluted in $100 \mathrm{~mL}$ drinking water during the interval between lunch and afternoon snack (Monday to Friday) for 45 class days. Attendance of the children and acceptance of the product were checked daily.

\section{Statistical analysis}

Statistical analyses were performed using Sigma Statistic for Windows (San Jose, CA); and results are presented as frequency, mean, standard deviation, and median. The data was checked for normality by the Kolmogorov-Smirnov test. Data of the blood parameters and food intake were analyzed by the Wilcoxon test to compare the groups in two stages, before and after the intervention. For anthropometric data, a paired-t test was used to compare the nutritional status before and after intervention. The Pearson correlation coefficient was applied to correlate the supplement intake with anthropometric, biochemical and dietary parameters. The association between categorical variables was investigated by the chisquare and Fischer tests. The $P$ level of 0.05 was considered as significant. 


\section{Results}

\section{Subjects}

Ninety-seven children ( 43 boys and 54 girls) aged 24 to 55 months (mean \pm standard deviation $=38.3 \pm 8.1$ months; median $=37$ months $)$ participated in the study and were submitted to anthropometric evaluation. Blood sampling was performed in 80 of these children, although serum ferritin, iron and retinol were analyzed in only 62 children due to the absence of some of the children on the days of blood sampling, insufficient blood volume and/or hemolysis.

\section{Anthropometry assessment}

At the beginning of the study, only $1.03 \%$ $(n=97)$ of the children showed low indices of stature for age (S/A) and weight for age (W/A), although the index weight for stature (W/S) was adequate. Of the children $6.2 \%$ were overweight based on their high weight for age (W/A) and for stature (W/S). The majority of the children $(92.8 \%)$ showed normal weight for age (W/A) and for stature (W/S) according to the World Health Organization $^{25}$. At the end of the intervention period there was an improvement in their anthropometric parameters (Table 2) and positive correlations between product intake and weight and stature (Table 3) were observed.

\section{Iron and vitamin A status}

Red blood cells (RBC), hemoglobin ( $\mathrm{Hb}$ ), hematocrit (Htc), mean corpuscular volume (MCV), mean corpuscular hemoglobin $(\mathrm{MCH})$, and ferritin were statistically higher after intervention, while serum iron was reduced (Table 2 ). No effect on serum retinol and mean corpuscular hemoglobin concentration (MCHC) was observed after intervention (Table 2). Positive significant correlations were observed between product intake and $\mathrm{RBC}, \mathrm{Hb}$ and Htc (Table 3 ).

Table 2. Anthropometric and biochemical parameters of the preschool children before and after the 45-day intervention with the supplement.

\begin{tabular}{|c|c|c|c|c|}
\hline & $\mathbf{n}$ & Before & After & p value \\
\hline Weight/age (z-score) & 97 & $\begin{array}{c}0.303 \pm 0.943 \\
(0.275)\end{array}$ & $\begin{array}{c}0.419 \pm 0.92 \\
(0.421)\end{array}$ & $p<0.001^{a}$ \\
\hline Height/age (z-score) & 97 & $\begin{array}{c}-0.004 \pm 1.12 \\
(0.029)\end{array}$ & $\begin{array}{c}0.047 \pm 1.11 \\
(0.146)\end{array}$ & $p=0.02^{a}$ \\
\hline BMI/age (z-score) & 97 & $\begin{array}{c}-0.35 \pm 2.05 \\
(15.91)\end{array}$ & $\begin{array}{l}0.22 \pm 2.10 \\
\quad(16.10)\end{array}$ & $p<0.001^{a}$ \\
\hline Erythrocytes (million $/ \mathrm{mm}^{3}$ ) & 80 & $\begin{array}{c}4.69 \pm 0.41 \\
\quad(4.69)\end{array}$ & $\begin{array}{c}4.78 \pm 0.37 \\
\quad(4.76)\end{array}$ & $p=0.026^{a}$ \\
\hline Hemoglobin $(\mathrm{g} / \mathrm{dL})$ & 80 & $\begin{array}{c}12.01 \pm 0.89 \\
(12.00)\end{array}$ & $\begin{array}{c}12.43 \pm 0.92 \\
(12.35)\end{array}$ & $p<0.001^{a}$ \\
\hline Hematocrit (\%) & 80 & $\begin{array}{c}36.72 \pm 2.71 \\
(36.50)\end{array}$ & $\begin{array}{c}38.19 \pm 2.36 \\
(37.95)\end{array}$ & $p<0.001^{a}$ \\
\hline $\mathrm{MCV}(\mathrm{fL})$ & 80 & $\begin{array}{c}78.48 \pm 4.71 \\
(78.33)\end{array}$ & $\begin{array}{c}80.03 \pm 4.86 \\
(80.81)\end{array}$ & $p<0.001^{a}$ \\
\hline $\mathrm{MCH}(\mathrm{pg})$ & 80 & $\begin{array}{c}25.70 \pm 1.81 \\
(25.96)\end{array}$ & $\begin{array}{c}26.06 \pm 1.96 \\
(26.45)\end{array}$ & $(p<0.001)^{b}$ \\
\hline $\mathrm{MCHC}(\mathrm{g} / \mathrm{dL})$ & 80 & $\begin{array}{c}32.74 \pm 1.22 \\
(32.58)\end{array}$ & $\begin{array}{c}32.55 \pm 1.15 \\
(32.43)\end{array}$ & $p=0.19^{a}$ \\
\hline Ferritin $(\mu \mathrm{g} / \mathrm{L})$ & 62 & $\begin{array}{c}29.36 \pm 18.89 \\
(27.00)\end{array}$ & $\begin{array}{c}54.36 \pm 60.99 \\
(37.00)\end{array}$ & $(p<0.001)^{b}$ \\
\hline Serum iron $(\mu \mathrm{g} / \mathrm{dL})$ & 62 & $\begin{array}{c}67.59 \pm 32.67 \\
(61.00)\end{array}$ & $\begin{array}{c}57.65 \pm 24.41 \\
(55.00)\end{array}$ & $p=0.03^{a}$ \\
\hline Serum retinol $(\mu \mathrm{g} / \mathrm{dL})$ & 62 & $\begin{array}{c}47.55 \pm 21.34 \\
(47.18)\end{array}$ & $\begin{array}{c}45.75 \pm 18.32 \\
(43.12)\end{array}$ & $(p=0.52)^{b}$ \\
\hline
\end{tabular}

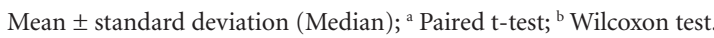




\section{Dietary intake}

The energy and nutrients intake was similar before and after research. However, the intervention significantly increased the intake of energy and all nutrients supplied by the product (proteins, carbohydrates, lipids, fiber, vitamin A, vitamin $\mathrm{C}$, calcium, iron, zinc and copper), as shown in Table 4 . Table 5 shows the prevalence of

Table 3. Correlation between supplement intake and anthropometric and biochemical parameters $(n=51)$.

\begin{tabular}{lcc} 
Variables (supplement intake $^{\mathrm{a}}$ ) & R values & p values \\
\hline Weight $^{\mathrm{b}}(\mathrm{kg})$ & 0.453 & $<0.001$ \\
Weight (z-escore) & 0.314 & 0.025 \\
Height $^{\mathrm{b}}(\mathrm{m})$ & 0.393 & 0.004 \\
Height $^{\mathrm{b}}(\mathrm{z}$-escore) & 0.243 & 0.085 \\
$\mathrm{BMI}^{\mathrm{b}}\left(\mathrm{kg} / \mathrm{m}^{2}\right)$ & 0.218 & 0.12 \\
Delta $^{\mathrm{c}}$ erythrocyte & 0.414 & 0.002 \\
Delta $^{\mathrm{c}}$ hemoglobin & 0.312 & 0.026 \\
Delta $^{\mathrm{c}}$ hematocrit & 0.398 & 0.003 \\
Delta $^{\mathrm{c}} \mathrm{MCV}$ & 0.08 & 0.587 \\
Delta $^{\mathrm{c}} \mathrm{MCH}$ & -0.204 & 0.151 \\
Delta $^{\mathrm{c}} \mathrm{MCHC}$ & -0.207 & 0.145 \\
Delta $^{\mathrm{c}}$ ferritin & 0.186 & 0.191 \\
Delta $^{\mathrm{c}}$ serum iron & -0.116 & 0.418 \\
\hline
\end{tabular}

${ }^{\mathrm{a}}$ supplement intake $=$ number of days $\mathrm{x}$ dairy intake $(\mathrm{g})$;

${ }^{\mathrm{b}}$ after intervention; ${ }^{\mathrm{c}}$ difference between final and initial values. micronutrient inadequacy (vitamin A, vitamin C, iron, zinc and copper) before and after intervention. The product was efficient in reducing dietary inadequacy of vitamin $\mathrm{A}$, iron and zinc by $100 \%$; while the inadequacy of vitamin $\mathrm{C}$ was reduced from $11.29 \%$ to $1.61 \%(n=62)$.

\section{Discussion}

The significant improvement in nutritional status derived from the intervention in the present study corroborates the results obtained in our previous work, in which Silva et al. ${ }^{6}$ observed higher weight and height gains than the reference preschool population ${ }^{25}$ following intervention with the milky beverage supplemented with iron and probiotics. Similarly, Vitolo et al. ${ }^{30}$ also showed significantly higher adequacy of the W/S index in undernourished children after 2 months of consuming an iron-enriched cereal.

High bioavailability of the essential amino acids present in the components of the product, such as whey protein, may have contributed for the positive impact of the product on anthropometric parameters of the preschool children, since protein intake was significantly correlated with weight and height after intervention. Whey proteins are known for their high digestibility and absorption and for promoting protein synthesis and body growth ${ }^{31,32}$.

Micronutrients supplied by the product, especially iron, zinc, copper, vitamin A and vitamin

Table 4. Intake of energy and nutrient (Mean \pm standard deviation; median) of preschool children at the beginning (without supplement) and at the end of intervention (with supplement) $(\mathrm{n}=62)$.

\begin{tabular}{lccccc}
\hline & \multicolumn{2}{c}{ Without supplement } & With supplement & \\
\cline { 2 - 6 } & Mean \pm SD & Median & Mean \pm SD & Median & p $^{*}$ \\
\hline Calories $(\mathrm{kcal})$ & $860.27 \pm 95.94$ & 833.98 & $980.46 \pm 95.94$ & 954.18 & $<0.001$ \\
Protein $(\mathrm{g})$ & $17.62 \pm 2.84$ & 18.04 & $23.72 \pm 2.84$ & 24.14 & $<0.001$ \\
Carbohydrate $(\mathrm{g})$ & $157.57 \pm 16.55$ & 152.0 & $176.57 \pm 16.55$ & 171.0 & $<0.001$ \\
Lipids $(\mathrm{g})$ & $17.72 \pm 3.77$ & 16.3 & $19.92 \pm 3.77$ & 18.5 & $<0.001$ \\
Vitamin A $(\mu \mathrm{g})$ & $256.58 \pm 101.19$ & 220.3 & $388.6 \pm 101.2$ & 352.3 & $<0.001$ \\
Vitamin C $(\mathrm{mg})$ & $27.25 \pm 14.02$ & 19.1 & $37.14 \pm 14.02$ & 29.0 & $<0.001$ \\
Calcium $(\mathrm{mg})$ & $179.8 \pm 69.1$ & 160.0 & $278.8 \pm 69.10$ & 259.0 & $<0.001$ \\
Iron $(\mathrm{mg})$ & $4.80 \pm 0.82$ & 4.8 & $6.8 \pm 0.82$ & 6.8 & $<0.001$ \\
Zinc $(\mathrm{mg})$ & $1.97 \pm 0.45$ & 1.9 & $3.3 \pm 0.46$ & 3.2 & $<0.001$ \\
Copper $(\mu \mathrm{g})$ & $459.68 \pm 109.3$ & 500.0 & $569.68 \pm 109.33$ & 610.0 & $<0.001$ \\
Fiber $(\mathrm{g})$ & $6.26 \pm 1.07$ & 6.8 & $9.46 \pm 1.07$ & 10.0 & $<0.001$ \\
\hline
\end{tabular}

*Wilcoxon test. 


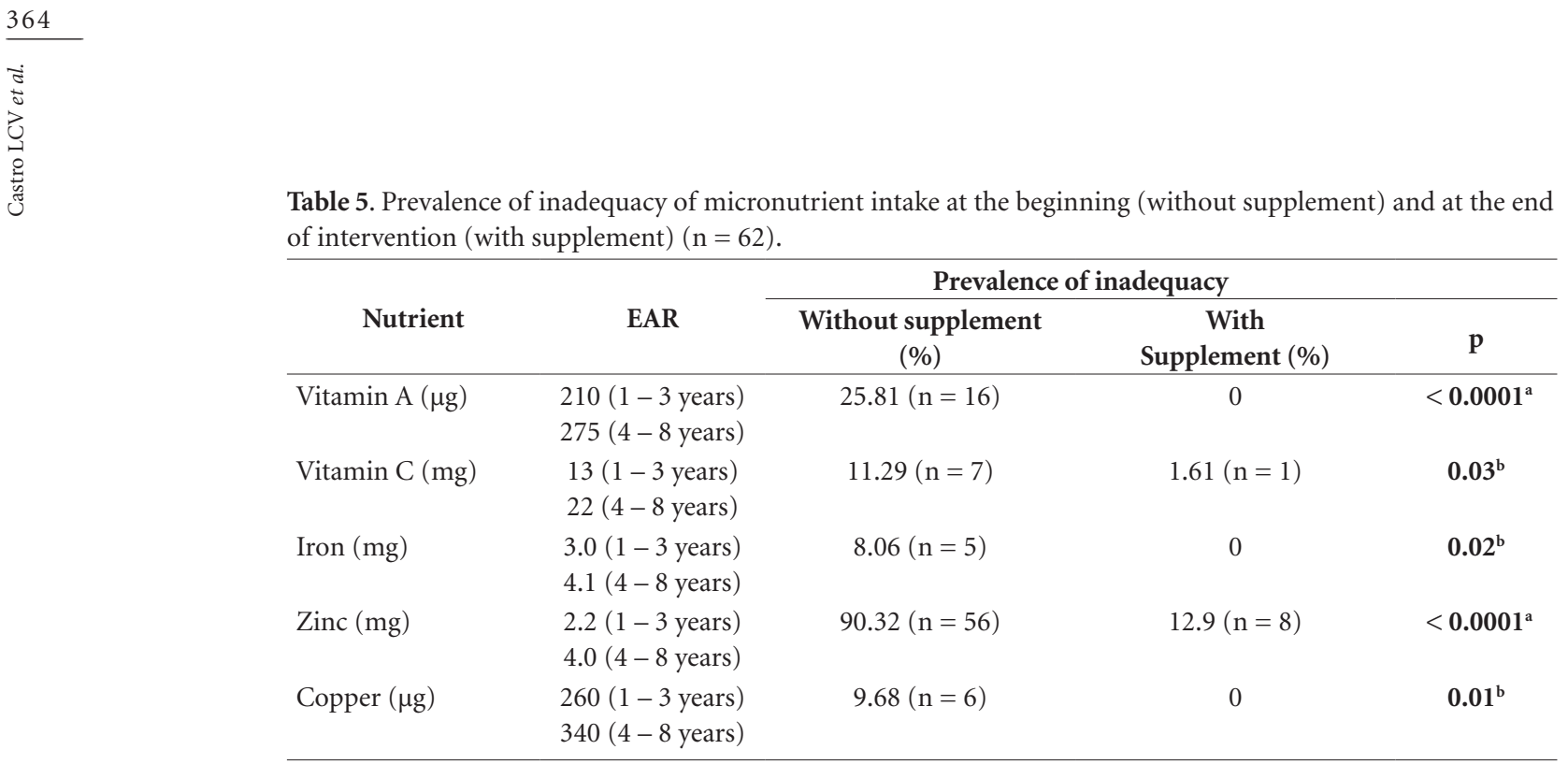

${ }^{\text {a }}$ Chi-square test; ${ }^{\text {b }}$ Fisher test.

C, may have also contributed to body growth, since they are involved in many anabolic reactions. Moreover, supplementation with multiple nutrients is more effective than single nutrient supplementation, as shown in a meta-analysis study carried out by Ramakrishnan et al. ${ }^{33}$. The authors reported the effects of food supplement on the growth of children and adolescents in randomized controlled studies where combined nutrients were used, including vitamin A and iron. Similarly, Chagan et al. ${ }^{34}$ performed a long-term controlled randomized double blind study in 6 to 24-month-old children in the rural area of South Africa and showed that supplementation with multiple nutrients (zinc, vitamin A, iron, copper, and vitamin C) from 2003 to 2009 was more effective in improving growth than vitamin A supplementation alone or combined only with zinc. Hieu et al. ${ }^{4}$ studied 381 school children in Vietnam and also found higher weight for stature (W/S) z-scores among those who received cookies fortified with multi-nutrients (iron, zinc, vitamin $\mathrm{C}$, vitamin $\mathrm{A}$, calcium and magnesium) for 6 months, compared to those who received a weekly iron supply of ferrous fumarate.

The improved iron status of children in the present study was superior to the results obtained in our previous study ${ }^{35}$, in which the intervention with an iron-fortified milky beverage supplemented with probiotics for 35 days significantly raised the levels of serum ferritin in preschool children. The combined fortification of our product with iron, vitamin A, vitamin $\mathrm{C}$, zinc, copper and inulin may have contributed to the significant improvement in levels of $\mathrm{RBC}, \mathrm{Hb}$, $\mathrm{Htc}, \mathrm{MCV}, \mathrm{MCH}$, and serum ferritin.
A positive association between iron and vitamin A was reported in the early 1980's by Mejía and Arroyave ${ }^{36}$ with preschool children participating in the sugar fortification program in Guatemala, in which the availability of serum iron for hematopoiese was improved by the addition of vitamin A. Mejía and $\mathrm{Chew}^{37}$ reported improvement in iron status, especially in serum iron of preschool and school children following $3 \mathrm{mg}$ daily supplementation of vitamin A. The study of Bloem et al. ${ }^{9}$ which utilized $110 \mathrm{mg}$ vitamin A supplementation for 2 weeks also showed increased concentrations of hemoglobin, hematocrit, serum iron, and transferrin saturation in 3 to 9-year-old vitamin A deficient children. The authors suggested that vitamin A has an effect on iron mobilization from reserves for hemoglobin synthesis, which increased iron absorption.

The effect of vitamin A on iron mobilization from body reserves has been confirmed more recently by Zimmermann et al. ${ }^{10}$, who reported higher $\mathrm{Hb}$ and MCV and lower ferritin concentrations in 5 to 13 -year-old children after 5 months of supplementation with 200,000 IU of vitamin A. Jimenez et al. ${ }^{11}$ also reported improved iron status after a 30-day intervention with a single dose of $60 \mathrm{mg}$ vitamin A in preschool children, while Willows et al. ${ }^{12}$ reported lower intake of vitamin A in anemic children.

The current study showed no correlation between product intake and serum retinol. Nevertheless, a negative correlation between serum retinol and ferritin was observed $(\mathrm{r}=-0.313$; $\mathrm{p}$ $=0.02$ ), which corroborates the hypothesis that vitamin A favors iron mobilization from reserves to erythrocytes synthesis ${ }^{10,13}$. 
The study conducted by Zimmermann et al. ${ }^{10}$ showed higher levels of erythropoietin after a 10-month intervention with vitamin A, indicating increased erythropoiesis, since this glycoprotein hormone is important for erythrocyte maturation. It is known that vitamin A metabolites act on the genetic regulation of erythropoietin synthesis and other hormones and cytokines involving red blood cell production ${ }^{13}$.

According to West Junior ${ }^{13}$, the mechanisms by which vitamin A interacts with iron may involve: a) liver iron reserve mobilization; b) erythropoiesis stimulation via erythropoietin; c) reduced infection and consequently reduced risk of anemia; and d) increased iron absorption, possibly due to the chelation effect of vitamin A in the gut, which protects dietary iron from inhibiting factors, such as phytate and polyphenols. Vitamin A is also involved in the iron regulator protein-2 (IRP2), and consequently affects gene expression of ferritin and transferrin synthesis ${ }^{14}$.

The composition of the product with respect to other nutrients, such as zinc, copper, and vitamin C, may have contributed to improve the iron status of preschool children in the present study. This assumption is supported by Ash et al. ${ }^{16}$ who performed a randomized double-blind study with 774 school children, in which the test group received a multinutrient-fortified beverage for 6 months. The test group showed significantly higher concentrations of serum ferritin and lower prevalence of vitamin A deficiency than the control group. Hyder et al. ${ }^{17}$ reported similar results in 1268 adolescents receiving orange juice fortified with iron, zinc, and vitamins A, C and complex B. After a 6-month intervention period, the test group compared with the control showed higher weight and height gains, higher concentrations of hemoglobin, serum ferritin and retinol, and lower prevalence of iron deficiency anemia. Hieu et al. ${ }^{4}$ also observed lower prevalence of iron deficiency anemia in children receiving multinutrient-fortified cookies containing iron, zinc, vitamin $\mathrm{A}$, vitamin $\mathrm{C}$, calcium and magnesium (1\%) when compared with the control group $(10.4 \%)$. Those who received a weekly iron supplementation showed an intermediate prevalence of anemia (7.4\%) after intervention.

The presence of other nutrients may improve iron absorption and metabolism ${ }^{18}$. It is known that vitamin $\mathrm{C}$ reduces ferric to ferrous iron, improving its absorption and bioavailability ${ }^{38}$; and that copper is required for ceruloplasmin synthesis, which oxidates ferrous to ferric iron to be bound to transferrin. Zinc is also necessary for iron metabolism and its deficiency alters erythropoiesis and reduces red blood cell resistance to oxidative stress ${ }^{39}$.

The addition of inulin may have contributed to the beneficial effects of the product on iron status in the present study. Prebiotic fermentation by the intestinal microbiota produces short chain fatty acids (SCFA) which reduce gut $\mathrm{pH}$ and hence reduce ferric to ferrous iron and increases its solubility. The production of SCFA also improves the height of vilus cripts, and consequently the area for nutrient absorption ${ }^{19}$. Prebiotics, such as inulin, oligofructose, glycooligosaccharides and galactooligosaccharides, have been associated with improved absorption and retention of minerals, particularly calcium, magnesium and iron ${ }^{40}$.

The product fortified with prebiotics, iron, zinc, copper, vitamin A and vitamin C efficiently improved the iron status of preschool children in the current study, possibly due to a synergistic effect of these compounds. Retinol levels were not altered which was probably due to channeling of vitamin A for iron metabolism and the production of red blood cells. Moreover, other factors may have contributed to prevent serum retinol from being affected including: 1) The relative low prevalence of vitamin A deficiency (serum retinol $<20 \mu \mathrm{g} / \mathrm{dL}$ ) among preschool children ( $4.8 \%$ before and $3.2 \%$ after intervention), which characterizes a light deficiency in this population group according to the $\mathrm{WHO}^{41}$. Serum retinol reflects the body reserves of vitamin A only when they are very high or very low. Therefore, they are not indicated as a sole diagnostic criteria at the individual level. At population levels, however, the frequency of serum retinol distribution is a reliable criteria for vitamin A deficiency assessment $t^{41,42}$. 2) The duration of the intervention (2 months) may have not been sufficiently long to evaluate the efficacy of the product on vitamin A status. Long-term studies have reported the efficacy of food fortification on vitamin A status, as shown by Ribaya-Mercado et al. ${ }^{43}$ in a 12 -month intervention program of sugar cane fortification. 3) The redistribution of vitamin A following iron fortification, as reported by Wieringa et al. ${ }^{44}$. The authors reported reduced serum retinol concentrations in infant children after iron fortification and suggested the redistribution of vitamin A from the blood stream to the liver and/or increased vitamin requirements for erythropoiesis.

There was no control of infections in the present study, limiting the interpretation of the results of serum iron, since in this condition 
there is observed increase in the intracellular iron and consequent reduction of serum iron ${ }^{45}$.

\section{Conclusion}

The food supplement contributed to increase the intake of nutrients, which in turn improved the nutritional status of preschool children. Multiple supplementation with protein, prebiotic, iron, zinc, copper, vitamin A and vitamin $\mathrm{C}$ seems to have synergistically worked to elevate anthropometric (stature and weight) and biochemical parameters (erythrocytes, hemoglobin, hematocrit, MCV, MCH and serum ferritin), although the vitamin A status presented no change. Use of this product is a promising strategy to improve nutritional and iron status of preschool children.

\section{Collaborations}

LCV Castro and NMB Costa contributed to project conception, conducting the interviews, analysis of the material, and drafting this manuscript. HMP Sant'Anna, CLLF Ferreira and SCC Franceschini participated in revising the article critically for important intellectual content. All the authors approved the final version for publication. 


\section{References}

1. Iost C, Name JJ, Jeppsen RB, Ashmead HD. Repleting hemoglobin in iron deficiency anemia in young children through liquid milk fortification with bioavailable iron amino acid chelate. J Am Coll Nutr 1998; 17(2):187-194

2. Pizarro F, Olivares M, Hertrampf E, Mazariegos DI, Arredondo M, Letelier A, Gidi V. Iron bis-glycine chelate competes for the nonheme-iron absorption pathway. Am J Clin Nutr 2002; 76(3):577-581.

3. Brasil. Ministério da Saúde (MS). Carência por micronutriente. Brasília: MS; 2007. Caderno de Atenção à Saúde, n.20.

4. Hieu NT, Sandalinas F, Sesmaisons A, Laillou A, Tam NP, Khan NC, Bruyeron O, Wieringa FT, Berger J. Multi-micronutrient-fortified biscuits decreased the prevalence of anaemia and improved iron status, whereas weekly iron supplementation only improved iron status in Vietnamese school children. Br J Nutr 2012; 108(8):1419-1427.

5. World Health Organization (WHO). Global prevalence of vitamin A deficiency in populations at risk 1995-2005. WHO Global Database on Vitamin A Deficiency. Geneva: WHO; 2009.

6. Silva MR, Dias G, Ferreira CLL, Franceschini SCC, Costa NMB. Growth of preschool children was improved when fed an iron-fortified fermented milk beverage supplemented with Lactobacillus acidophilus. Nutr Res 2008; 28(4):226-232.

7. Al-Mekhlafi HM, Al-Zabedi EM, Al-Maktari MT, Atroosh WM, Al-Delaimy AK, Moktar N, Sallam AA, Abdullah WA, Jani R, Surin J. Effects of vitamin A supplementation on iron status indices and iron deficiency anaemia: a randomized controlled trial. Nutrients 2014; 6(1):190-206.

8. De-Regil LM, Suchdev PS, Vist GE, Walleser S, Peña-Rosas JP. Home fortification of foods with multiple micronutrient powders for health and nutrition in children under two years of age (Review). Evid Based Child Health 2013; 8(1):112-201.

9. Bloem MW, Wedel M, Agtmaal EJV, Speek AJ, Saowakontha S, Schreurs WHP. Vitamin A intervention: short-term effects of a single, oral, massive dose on iron metabolism. Am J Clin Nutr 1990; 51(1):76-79.

10. Zimmermann MB, Biebinger R, Rohner F, Dib A, Zeder C, Hurrel R, Chaouki N. Vitamin A supplementation in children with poor vitamin A and iron status increases erythropoietin and hemoglobin concentrations without changing total body iron. Am J Clin Nutr 2006; 84(3):580-586.

11. Jimenez C, Leets I, Puche R, Anzola E, Montilla R, Parra C, Aguilera A, García-Casal MN. A single dose of vitamin A improves haemoglobin concentration, retinol status and phagocytic function of neutrophils in preschool children. Br J Nutr 2010; 103(6):798-802.

12. Willows ND, Barbarich BN, Wang LCH, Olstad DL, Clandinin MT. Dietary inadequacy is associated with anemia and suboptimal growth among preschool-aged children in Yunnan Province, China. Nutr Res 2011; 31(2):88-96.

13. West Junior K. Vitamin A in nutritional anemia. In: In: Kramer K, Zimmermann MB, editors. Nutritional Anemia. Geneva: Sight and Life Press; 2007. p.133-154
14. Jiang S, Wang C, Lan L, Zhao D. Vitamin A deficiency aggravates iron deficiency by upregulating the expression of iron regulatory protein-2. Nutr 2011; 28(3):281-287.

15. Costa NMB. Minerais. In: Costa NMB, Peluzio MCG, organizadores. Nutrição Básica e Metabolismo. Viçosa: Ed. UFV; 2008. p. 263-359.

16. Ash DM, Tatala SR, Frongillo EA, Latham MC. Randomized efficacy trial of a micronutrient-fortified beverage in primary school children in Tanzania. Am J Clin Nutr 2003; 77(4):891-898

17. Hyder SM, Haseen F, Khan M, Jalal CSB, Mannar V, Mehansho HA. Multiple-Micronutrient-Fortified Beverage Affects Hemoglobin, Iron, and Vitamin A Status and Growth in Adolescent Girls in Rural Bangladesh. J Nutr 2007; 137(9):2147-2153.

18. Allen LH, Peerson JM, Olney DK. Provision of multiple rather than two or fewer micronutrients more effectively improves growth and other outcomes in micronutrient-deficient children and adults. J Nutr 2009; 139(5):1022-1030.

19. Shols-Ahrenz KE, Schaafsma G, Van Den Heuvel EG, Schrezenmeir J. Effects of prebiotics on mineral metabolism. Am J Clin Nutr 2001; 73(2 Supl.):459S-464S.

20. Yasuda K. Supplemental Dietary Inulin Affects the Bioavailability of Iron in Corn and Soybean Meal to Young Pigs. J Nutr 2006; 136(12):3033-3038.

21. Institute of Medicine (IOM). Dietary reference intakes for vitamin A, vitamin E, selenium and carotenoids. Washington: National Academy Press; 2000.

22. Institute of Medicine (IOM). Dietary reference intakes for vitamin $C$, vitamin $K$, arsenic, boron, chromium, copper, iodine, iron, manganese, molybdenum, nickel, silicon, vanadium and zinc. Washington: National Academy Press; 2001.

23. Brasil. Ministério da Saúde (MS). Resolução RDC n 269, de 22 de setembro de 2005. Regulamento Técnico Sobre A Ingestão Diária Recomendada (IDR) De Proteína, Vitaminas e Minerais. Diário Oficial da União 2005; 23 set.

24. Jelliffe DB. The assessment of the nutritional status of the community. Geneva: WHO; 1966.

25. World Health Organization (WHO). WHO Child Growth Standards: Length/height-for-age, weight-forage, weight-for-length,weight-for-height and body mass index-for-age. Methods and development. Geneva: WHO; 2006

26. Sauberlich HE. Laboratory tests for the assessment of nutritional status. $2^{\text {nd }}$ ed. New York: CRC Press Ltd.; 1999.

27. Netto MP. Estado nutricional de ferro e vitamina A em crianças de 18 a 24 meses do município de Viçosa, Minas Gerais [dissertação]. Viçosa: Universidade Federal de Viçosa; 2005.

28. Weinmann ARM, Oliveira MS, Jorge SM, Martins AR. Simultaneous high-performance liquid chromatographic determination of retinol by fluorometry and of tocopherol by ultraviolet absorbance in the serum of newborns. J Chromatogr B 1999; 729(1-2):231-236.

29. Institute of Medicine (IOM). Dietary reference intakes for energy, carbohydrate, fiber, fat, fatty acids, cholesterol, protein and amino acids. Washington: National Aca- 
demy Press; 2002.

30. Vítolo MR, Aguirre ANC, Kondo MR, Giuliano Y, Ferreira N, Lopez FA. Impacto do uso de cereal adicionado de ferro sobre níveis de hemoglobina e a antropometria em pré-escolares. Rev Nutr 1998; 11(2):163-171.

31. Zinsly PF, Sgarbieri VC, Pereira Dias NFG, Jacobucci HB, Pacheco MTB, Baldini VLS. Produção piloto de concentrados de proteínas de leite bovino: composição e valor nutritivo. Braz J Food Technol 2001; 4(11):1-8.

32. Sgarbieri VC. Propriedades estruturais e físico-químicas das proteínas do leite. Braz J Food Technol 2005; 8(185):43-56.

33. Ramakrishnan U, Aburto N, McCabe G, Martorell R. Multimicronutrient Interventions but Not Vitamin A or Iron Interventions Alone Improve Child Growth: Results of 3 Meta-Analyses. J Nutr 2004; 134(10):25922602.

34. Chagan M K, Van Den Broeck J, Luabeya KKA, Bennish ML. Effect on longitudinal growth and anemia of zinc or multiple micronutrients added to vitamin A: a randomized controlled trial in children aged 6-24 months. BMC Public Health 2010; 10:145.

35. Silva MR, Castro TG, Costa NMB, Ferreira CLLF, Franceschini SCC, Leal PFG, Reis FP. Efeito de uma bebida Láctea fermentada e fortificada com ferro sobre o estado nutricional de ferro em pré-escolares. Viçosa-MG. Nutrire: Rev Soc Bras Alim Nutr 2002; 23(1):23-32.

36. Mejía LA, Arroyave G. The effect of vitamin A fortification of sugar on iron metabolism in preschool children in Guatemala. Am J Clin Nutr 1982; 36(1):87-93.

37. Mejía LA, Chew F. Hematological effect of supplementing anemic children with vitamin A alone and in combination with iron. Am J Clin Nutr 1988; 48(3):595-600.

38. Hurrel R, Egli I. Iron bioavailability and dietary reference values. Am J Clin Nutr 2010; 91(5 Supl.):1461S1467S.

39. Olivares M, Hertrampf E, Uavy R. Copper and zinc interactions in anemia: a public health perspective. In: Kramer K, Zimmermann MB, editors. Nutritional Ane- mia. Geneva: Sight and Life Press; 2007. p. 99-110.

40. Sant'Anna MSL, Ybarra LM, Paula HAA, Costa NMB, Ferreira CLLF. Probióticos e prebióticos na absorção de minerais. In: Ferreira CLLF, organizador. Prebióticos e probióticos - atualização e prospecção. Rio de Janeiro: Editora Rúbio; 2012. p. 57-71.

41. World Health Organization (WHO). Indicators for assessing vitamin $A$ deficiency and their application in monitoring and evaluating intervention programs. Geneva: WHO; 1996.

42. Pee S, Dary O. Biochemical Indicators of Vitamn A Deficiency: Serum Retinol and Serum Retinol Binding Protein. J Nutr 2002; 132 (9 Supl.):2895S-901S.

43. Rybaia-Mercado JD, Solomons NW, Medrano Y, Bulux J, Dolnikowski GG, Russel RM, Wallace CB. Use of the deuterated-retinol-dilution technique to monitor the vitamin A status of Nicaraguan schoolchildren $1 \mathrm{y}$ after initiation of the Nicaraguan national program of sugar fortification with vitamin A. Am J Clin Nutr 2004; 80(5):1291-1298.

44. Wieringa TF, Dijkhuizen AM, West EC, Thurnham ID, Muhilal Van Der Meer MW. Redistribution of vitamin A after iron supplementation in Indonesian infants. Am J Clin Nutr 2003; 77(3):651-657.

45. Wieringa FT, Dijkhuizen MA, West CE, Northrop-Clewes CA, Muhilal. Estimation of the effect of the acute phase response on indicators of micronutrients status in Indonesian infants. J Nutr 2002; 132(10):3061-3066.

Artigo apresentado em 13/05/2015

Aprovado em 27/11/2015

Versão final apresentada em 29/11/2015 